\title{
Postpartum tricuspid staphylococcal endocarditis complicated with multiple pulmonary pseudomonal abscesses
}

\author{
Suleyman Ercan, ${ }^{1}$ Emine Sari, ${ }^{2}$ Vedat Davutoglu, ${ }^{1} \mathrm{Cem} \mathrm{Kis}^{3}$
}

${ }^{1}$ Department of Cardiology, Gaziantep University, Gaziantep, Turkey

${ }^{2}$ Department of Pediatrics, Nizip State Hospital,

Gaziantep, Turkey

${ }^{3}$ Department of Internal

Medicine, Gaziantep University, Gaziantep, Turkey

\section{Correspondence to}

Dr Suleyman Ercan,

sleymanercan@yahoo.com

\footnotetext{
To cite: Ercan S, Sari $\mathrm{E}$ Davutoglu V, et al. BMJ Case Rep Published online: [please include Day Month Year] doi:10.1136/bcr-2012008469
}

\section{DESCRIPTION}

A 24-year-old woman gave birth to a baby boy by a caesarean section in a local hospital. It was reported that a central venous catheter was implanted, because she had problems with bowel movements and peripheral venous access. Four days after implantation of the central venous catheter, she felt feverish and her body temperature was recorded to be $38.8^{\circ} \mathrm{C}$. Upon admission, a physical examination revealed 4/6 pansystolic murmur over the left lower sternal border. Transthoracic echocardiography revealed a fluttering vegetation, 0.9 by $2.9 \mathrm{~cm}$, on the tricuspid valve with severe tricuspid regurgitation. Blood cultures yielded methicillinresistant Staphylococcus aureus. Despite appropriate antibiotic treatment with intravenous vancomycin and gentamicin her clinical status was complicated with right heart failure. The patient underwent a surgery and the tricuspid valve was replaced with bioprosthetic valve. After surgery, although the bioprosthetic valve was functional, third-degree atrioventricular block developed and coarse rhonchi occurred. Chest radiograph and CT revealed pleural effusion, bilateral multiple cavitations with air-liquid levels and well-defined margins (Figure 1A,B). Radiographic findings were compatible with the presence of multiple pulmonary abscesses. Her repeated blood cultures yielded Pseudomonas aeruginosa. Third-degree atrioventricular block persisted the following 2 weeks and a DDD-R permanent pacemaker was implanted into her. After being treated with intravenous piperacillin-tazobactam combination for 8 weeks, the patient recovered and chest radiography showed that the lung abscesses had recovered. To our knowledge, although pulmonary emboli and abscess formation in the course of endocarditis have been reported, ${ }^{1}$ postpartum tricuspid staphylococcal endocarditis complicated with multiple pulmonary pseudomonal abscesses has not been reported earlier.

\section{Learning points}

- Although right-sided endocarditis is commonly encountered in subjects with intravenous drug users, especially in those infected with HIV it may occur without such history.

- Need for central venous catheterisation should be decided carefully to prevent potentially life-threatening complications and if implanted, every effort should be made to prevent development of infections such as endocarditis.

- A thorough evaluation of the patient including detailed history taking, dedicated physical examination and clinical suspicion is still the key element in the diagnosis of infective endocarditis, although laboratory and various high-tech imaging modalities guide us for definitive diagnosis and appropriate treatment.

- Repeated physical examinations and close follow-up in the course of endocarditis is mandatory in order not to omit rapidly evolving clinical conditions and complications such as atrioventricular block and abscess development.

- Blood cultures should be repeated during treatment because the clinical scenario might be complicated by another infectious agent. 
(a)

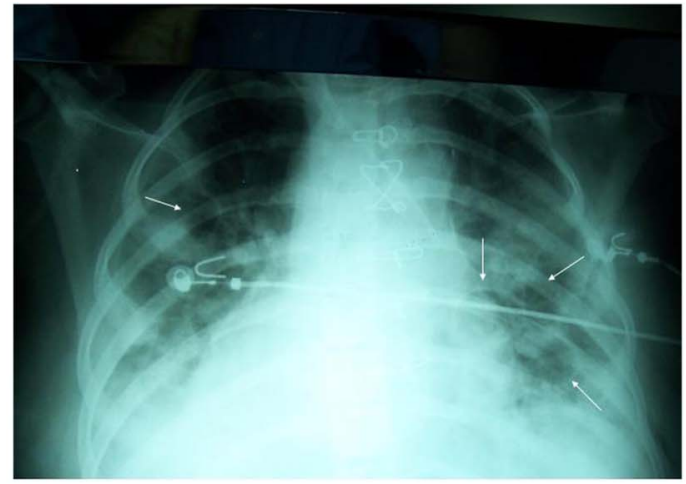

(b)
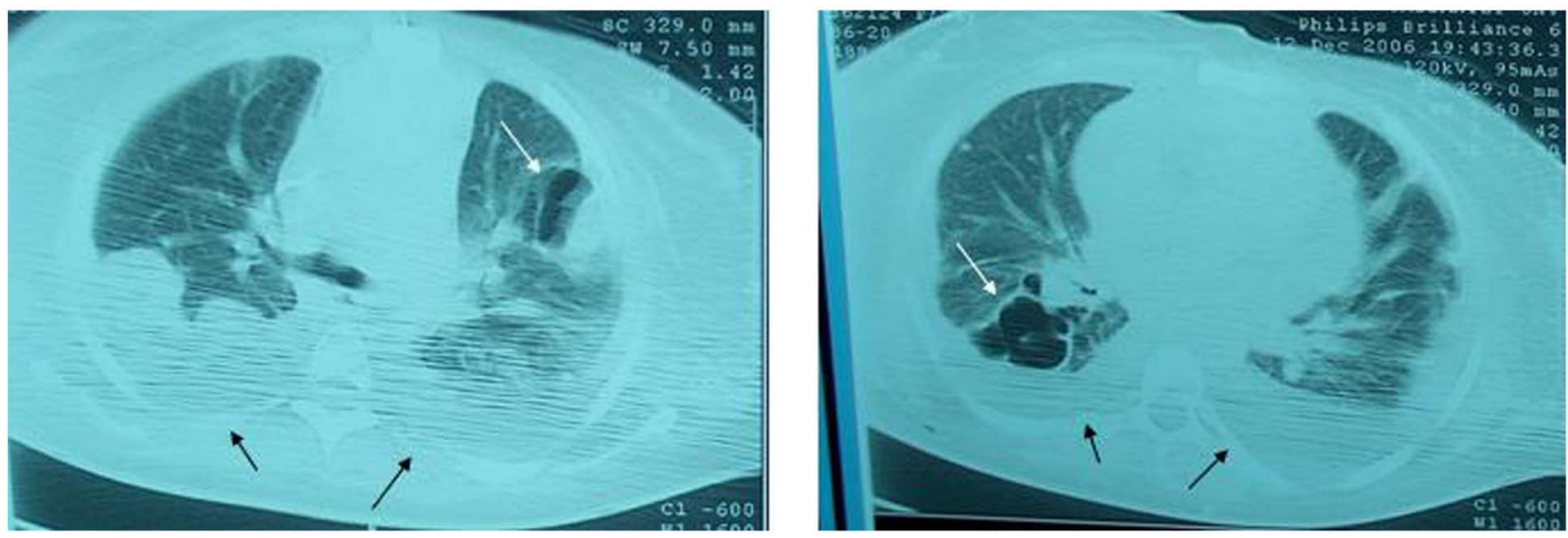

Figure 1 (A) Chest radiograph of the patient, bilateral multiple cavitations with air-liquid levels and well-defined margins (white arrows). (B) CT of the patient revealing pleural effusion (black arrows), bilateral multiple cavitations with air-liquid levels and well-defined margins (white arrows).

\section{Competing interests None.}

Patient consent Obtained.

Provenance and peer review Not commissioned; externally peer reviewed.

\section{REFERENCE}

1 Chen JY, Li YH. Images in clinical medicine. multiple pulmonary bacterial abscesses. N Engl J Med 2006;355:e27.

Copyright 2013 BMJ Publishing Group. All rights reserved. For permission to reuse any of this content visit http://group.bmj.com/group/rights-licensing/permissions.

BMJ Case Report Fellows may re-use this article for personal use and teaching without any further permission.

Become a Fellow of BMJ Case Reports today and you can:

- Submit as many cases as you like

- Enjoy fast sympathetic peer review and rapid publication of accepted articles

- Access all the published articles

- Re-use any of the published material for personal use and teaching without further permission

For information on Institutional Fellowships contact consortiasales@bmjgroup.com

Visit casereports.bmj.com for more articles like this and to become a Fellow 